\title{
Mental health and life satisfaction in a sample of students from Northern Chile
}

\author{
Jerome Flores-Jara ${ }^{1}$, Alejandra Caqueo-Urízar², Guillermo Vega-Latorre ${ }^{1}$, Aura Zepeda-Gómez ${ }^{1}$, \\ Yanira Rivera-Bartolo ${ }^{1}$ and Nechelle González-Ramírez ${ }^{1}$
}

${ }^{1}$ Universidad de Tarapacá y Centro de Justicia Educacional, Arica, Chile

${ }^{2}$ Universidad de Tarapacá e Instituto de Alta Investigación, Arica, Chile

\begin{abstract}
It is important to specifically understand which are the mental health variables that affect the life satisfaction of children and adolescents most, in order to optimally design programs aimed at promoting their wellbeing. The relationship between mental health and life satisfaction in students aged 9 to 18 years from Northern Chile was analyzed. A correlational cross-sectional study was carried out, using the Assessment System for Children and Adolescents (SENA) and the Satisfaction with Life Scale (SWLS-C). A total sample of 3455 students was used, divided into primary and secondary school students. Two structural equation models with good fit were obtained. In both, depression, self-esteem and age were maintained. Among primary school students there also emerged problems with school. However, among secondary school students, problems related to family and gender appeared. The relationship was stronger concerning secondary school. Implications for public policies and interventions are discussed.
\end{abstract}

Keywords: Mental health; life satisfaction; children; adolescents; self-esteem; wellbeing.

Salud mental y satisfacción con la vida en una muestra de estudiantes del norte de Chile

Resumen: Es relevante comprender específicamente cuales son las variables de salud mental que más afectan la satisfacción con la vida en la población infanto-juvenil para un diseño óptimo de programas de promoción de su bienestar. Se analizó la relación entre salud mental y satisfacción con la vida en estudiantes de 9 a 18 años del Norte de Chile. Se realizó un estudio transversal correlacional, empleando el Sistema de Evaluación de Niños y Adolescentes (SENA) y la escala de satisfacción con la vida (SWLS-C). Se utilizó una muestra total de 3455 estudiantes, dividida en primaria y secundaria. Se obtuvo dos modelos de ecuaciones estructurales con buen ajuste. En ambos se mantuvieron depresión, autoestima y edad. En primaria también apareció problemas con la escuela. En tanto, en secundaria apareció problemas con la familia y género. La relación fue más estrecha en esta última. Se discuten las implicaciones para focalizar políticas públicas e intervenciones.

Palabras clave: Salud mental; satisfacción con la vida; niños; adolescentes; autoestima; bienestar.

\section{Introduction}

Mental health affects several areas of a person's quality of life, and the absence of mental disorders does

Recibido: 06 de septiembre 2020; aceptado: 02 de julio 2021 Corresponding author: Jerome Flores-Jara, Escuela de Psicología y Filosofía, Universidad de Tarapacá y Centro de Justicia Educacional, Avenida 18 de septiembre 2222, 1010228 Arica, Chile. E-mail: jflores@uta.cl Acknowledgments: This research has been funded by ANID PIA CIE160007. not necessarily imply the presence of good health (World Health Organization, 2017). In the comparative study by Rescorla et al. (2011), Chile not only obtains a significantly higher average total score than the rest of the 23 countries evaluated, but also scores high on the specific scales of internalized and externalized problems in children and on the seven scales that assessed disorders related to the Diagnostic and Statistical Manual of Mental Disorders DSM-IV (American Psychiatric Association, 1994).

In this same country, the more recent study of prevalence indicates that a third of the child and adolescent population 
presents some psychiatric problems in a period of 12 months, being the prevalence higher in children than in adolescents. Furthermore, both groups prefer to use services in the school context, although most of those who are diagnosed do not receive attention (Vicente et al., 2012); it is noted that there is a $66.7 \%$ care gap for any type of disorder, which increases to $85.5 \%$ when only the formal health system is considered. Additionally, the low-income population is significantly less likely to receive help to resolve their emotional problems (Araya et al., 2006).

Mental health is transversal to the lives of students and has not only a welfare consequence but also a developmental one. Childhood and adolescence are critical periods for the formation of cognitive patterns of self, both positive and negative, which are stable over time and associated with satisfaction with the life of children (Cherry et al., 2020).

An impact on several areas of life, both present and future, is observed in students who have low life satisfaction (Nishida et al., 2016). This includes aspects such as their social relationships (Forrest et al., 2013), social skills (In et al., 2019), their school performance (Forrest et al., 2013), their strengths (Cherry et al., 2020), and their self-efficacy (Cherry \& Lumley, 2019), among others. Besides, positive affects, essential to a child's wellbeing, predict satisfaction in adult life (Coffey et al., 2015). Studies also show that as age increases, life satisfaction tends to decrease (Goldbeck et al., 2007; Haranin et al., 2007; Soares et al., 2019). Low life satisfaction is associated with a wide range of risk behaviors (Guzmán et al., 2020). These include suicidal ideation (Valois et al., 2004), excessive use of alcohol, and other drugs (Zullig, Valois et al., 2001), and sexual risk behaviors (Valois et al., 2002).

On the other hand, mental health is associated with satisfaction with life in this age group, whether one considers internalized problems (Moksnes et al., 2016) or externalized ones (Lyons et al., 2014). Their partnership has also been established over time (Lombardo et al., 2018). A longitudinal study found that both internalized and externalized problems have an effect on life satisfaction. However, the effect of internalized problems was greater and remained despite the inclusion of parental mediating variables (Zhu \& Shek, 2020). However, such research is limited to considering only two internalized and two externalized problems.

The directionality of the relationship has been proposed both from mental health to life satisfaction and in the opposite direction (Huebner, 2004). The mediation effect of life satisfaction between mental health and other variables has also been explored (Guzmán et al., 2020). However, this relationship has not been investigated in Chile. This is especially relevant given the state of mental health mentioned above. Additionally, there are few studies at the international level that analyze a broad spectrum of mental health problems that include both internalized, externalized, contextual, as well as personal resources in a single study. A detailed analysis that considers the contribution of each item in each dimension, through an analysis of structural equations, is also a possible contribution of this study. A comparison between 73 countries found differences in life satisfaction of adolescents being greater in males than females (Campbell et al., 2020). This is consistent with previous studies (Fernández-Pintos et al., 2019; KayeTzadok et al., 2017; Soares et al., 2019).

According to Bronfenbrenner's ecological model (1979, 1990), children develop in continuous interactions with their environment at different levels, being central the relationships with their family, school, and peers. Therefore, it would be expected to find an effect of the problems that arise in these contexts on satisfaction with life. Not enough attention has been paid to this relationship, although some studies have addressed the relationship of life satisfaction and stress within the family context (Chappel et al., 2014), and family support (Calmeiro et al., 2018). A recent qualitative study conducted in Chile concluded that for adolescents, a central aspect of life satisfaction is feeling loved and supported by significant adults (Alfaro-Inzunza et al., 2019). Evidence supporting the ecological model has been found in ten-year-old children in a comparison of 11 countries, including Chile. Relationships with parents, peers, and school are significant predictors of life satisfaction (Lawler et al., 2017). Nevertheless, at least one study has found a significant relationship between life satisfaction and the relationships children establish with adults in their home, school, and neighborhood, as well as with their peers, but was also limited to the same age (Gadermann et al., 2016). Therefore, considering a wider age range could be a contribution to understanding this relationship. Among personal resources, social skills and social competence have been found to be significantly associated with life satisfaction in adolescents (Calmeiro et al., 2018; Nesi de Mello et al., 2019). Self-esteem has also been found to be directly related to life satisfaction (Moksnes \& Espnes, 2013).

The objective of this study was to analyze the relationship between mental health and life satisfaction in a sample of students from 9 to 18 years old belonging to educational establishments in the city of Arica, located in the North of Chile. In accordance with the above, the research hypotheses were: 1) Internalized and externalized problems have a significant negative effect on life satisfaction, and the first are strong significance; 2) Contextual problems have a significant negative effect on 
life satisfaction; 3) Personal resources have a significant positive effect on life satisfaction; 4) Being male is associated with increased life satisfaction and 5) Age has a significant negative effect on life satisfaction.

\section{Method}

\section{Participants}

The total sample included 3455 students. Two samples were considered since different versions of the SENA instrument were applied, according to the courses to which the students belong. Both samples included public, government-subsidized, and private schools in Arica. Table 1 presents the baseline of sociodemographic characteristics. The elementary sample was 1300 students between the fourth and sixth grades. A total of $45.9 \%$ of the participants were men, and $54.1 \%$ were women. The age range was from 9 to 11 years old $(M=10, S D=0.79)$.

The secondary school sample was made up of 2155 students between the seventh and twelfth grades. The participants were $49.5 \%$ male and $50.5 \%$ female. The age range was 12 to 18 years. The mean age was 14.4 years, and the standard deviation was 1.7 years.

Tabla 1. Descriptive statistics

\begin{tabular}{|c|c|c|c|c|c|}
\hline \multirow{2}{*}{\multicolumn{2}{|c|}{ Variable }} & \multicolumn{2}{|c|}{ Primary } & \multicolumn{2}{|c|}{ Secondary } \\
\hline & & $n$ & $\%$ & $n$ & $\%$ \\
\hline \multicolumn{6}{|l|}{ Gender } \\
\hline & Female & 703 & 54.1 & 1088 & 50.5 \\
\hline & Male & 597 & 45.9 & 1067 & 49.5 \\
\hline \multicolumn{6}{|l|}{ Age } \\
\hline & & 400 & 30.8 & & \\
\hline \multicolumn{6}{|c|}{9} \\
\hline & 10 & 497 & 38.2 & & \\
\hline & 11 & 403 & 31.0 & & \\
\hline & 12 & & & 391 & 18.1 \\
\hline & 13 & & & 422 & 19.6 \\
\hline & 14 & & & 366 & 17.0 \\
\hline & 15 & & & 361 & 16.8 \\
\hline & 16 & & & 284 & 13.2 \\
\hline & 17 & & & 279 & 12.9 \\
\hline & 18 & & & 52 & 2.4 \\
\hline \multirow[t]{10}{*}{ Grade } & & 475 & 36.5 & & \\
\hline & $4^{\circ}$ & & & & \\
\hline & $5^{\circ}$ & 459 & 35.3 & & \\
\hline & $6^{\circ}$ & 366 & 28.2 & & \\
\hline & $7^{\circ}$ & & & 447 & 20.7 \\
\hline & $8^{\circ}$ & & & 444 & 20.6 \\
\hline & $9^{\circ}$ & & & 389 & 18.1 \\
\hline & $10^{\circ}$ & & & 336 & 15.6 \\
\hline & $11^{\circ}$ & & & 296 & 13.7 \\
\hline & $12^{\circ}$ & & & 243 & 11.3 \\
\hline \multicolumn{6}{|c|}{ Type of school } \\
\hline & Public & 490 & 37.7 & 882 & 40.9 \\
\hline & Subsidized & 728 & 56.0 & 1191 & 55.3 \\
\hline & Private & 82 & 6.3 & 82 & 3.8 \\
\hline
\end{tabular}




\section{Procedure and design}

It was a non-experimental type of study since no variables are manipulated. The design it was crosssectional correlational because all the variables were measured at one time (Hernández et al., 2010).

The approval of the Ethics Committee of the University of Tarapacá was obtained. This study was part of a larger project of the Educational Justice Center. Incidental or convenience sampling was conducted. Then, 42 educational establishments in the city of Arica were invited to participate in the study. A total of $69 \%$ agreed to participate, considering 29 establishments in total. Once permission was granted to enter the regular meetings with the school directors, the parents were asked for their consent after the purpose and scope of the study were explained. Finally, the evaluation within each course group was scheduled with the directors. Before starting, the consent of the students themselves was requested among those who were already authorized to participate. Students answered in paper and pencil format. At least two trained interviewers were present to answer the doubts, together with the teacher of the same course. The duration was approximately 45 minutes.

\section{Instruments}

Child and Adolescent Assessment System (SENA; Fernández-Pinto et al., 2015). This is an instrument originally developed in the Spanish language. It has different versions according to the age of the students, as well as versions for different informants, including student self-report, family and school. In the present study, two self-report versions were used, from 8 to 12 years and from 12 to 18 years, respectively. Approximately $70 \%$ of the items have the same wording and the rest vary slightly according to age group. It assesses a wide variety of scales, which can be grouped mainly into internalized problems, externalized problems, contextual problems, and personal resources. The detail of the grouped subscales belonging to each version can be seen in Tables 2 and 3, respectively. The answer format is a 5-option rating, from «never or almost never» to «always or almost always.» A higher score implies a greater presence of what each scale measures. The reliability of the original version is around $\alpha=.7$ for all scales (Sánchez-Sánchez et al., 2016). The validation in Chile is in the process of peer review, with the average values of $a$ and $\omega$ for each scale being .79 for the primary version (8-12) and .80 for the secondary school version (12-18). In the present study, the reliability was within the same values for both versions. The total reliability for the primary school versions was $\alpha=.95$, and $\alpha=.97$ for the secondary school version. The primary school version has 16 scales, and the secondary school version has 23 scales, in both the average of items per scale is 8 . This instrument also has an inconsistency scale that allows discarding cases with high inconsistency in their responses. Some items examples are: «I enjoy things less than before» (Depression); «My worries last a long time» (Anxiety); «I am afraid of making a fool of myself» (Social Anxiety); «I have a hard time concentrating» (Attention problems); «I have a hard time being calm about doing things» (Hyperactivity-Impulsiveness); «I have problems at home» (Family problems); «My classmates treat me badly» (Peer problems); «I like the way I am» (Self-esteem).

Satisfaction with Life Scale-Child (SWLS-C; Diener et al., 1985; Spanish version by Álvarez et al. (2018). It is a brief five-item instrument designed to measure global cognitive judgments about life satisfaction. Each item is scored on a 5-point Likert scale, from 1 (strongly disagree) to 5 (strongly agree). Its structure is one-dimensional and has been used in several countries (Diener, 2009). It was adapted to children by Gadermann et al. (2010). This scale has been validated in Chile and has obtained evidence of reliability according to Cronbach's Alpha of .82 (Álvarez et al., 2018). An example item is «My life is like the life I would like to have.» The reliability in the present study was $\alpha=.83$ for the primary school sample, and $\alpha=.87$ for the secondary school sample.

\section{Statistical analyses}

A progressive analysis was conducted to meet the study's objective of establishing the relationship between mental health and life satisfaction in this population. The correlations and multiple linear regression correspond to a first generation of analysis techniques, which has several limitations. On the other hand, structural equations (SEM) belong to a second generation of data analysis techniques that allow more complex and precise analyses in causal models, considering a better handling of the error, as well as making possible the use of latent variables (Lowry \& Gaskin, 2014). Therefore, this study seeks to reach this last level of complexity to analyze the data.

First, the sociodemographic descriptives of both samples were calculated. Then the correlations between the variables, which are the basis for considering which variables can be introduced in the SEM model. Before proposing a general model, analyses were carried out by sub-groups (internalized and externalized problems, contextual problems and personal resources) to establish which variables are most relevant to be included in the general models of each sample. Subsequently, model tests were carried out until alternatives with sufficient 
consistency and adjustment were found. This allowed the most relevant variables to be retained in the final models.

The automated electronic correction of the instruments allows up to $10 \%$ of unanswered questions, so those cases that exceeded that percentage were immediately discarded. The imputation of the lost values was used, which did not exceed $1 \%$ of the answers to each reagent. Cases with an inconsistency score equal to or greater than 1.6 were eliminated according to the recommendation of the SENA authors. The cases that were under the lower age limit in both versions were discarded. Additionally, 24 cases of 8-year-olds were discarded in the primary school because they were a very small group, as well as those of 12-year-olds who would have responded to this version since from that age onwards, the secondary school sample was considered.

The basic statistics of life satisfaction and the dimensions of the SENA in each sample, were considered categorical variables. Then it was considered the polychoric correlations between life satisfaction, age, and the different scales in each version of the SENA self-report. Subsequently, the structural equation models generated for each sample were proposed with their respective goodness-of-fit indexes. In the structural equations, the estimator used in the models was the Robust Weighted Least Square (WLSMV) since it is robust to non-normality ( $\mathrm{Li}, 2016)$.

When analyzing goodness-of-fit, by convention, an RMSEA below 0.08 is acceptable, and below 0.05 is optimal, while a CFI and TLI above 0.9 are acceptable, and above 0.95 are optimal. While an SRMR around or below 0.8 is adequate (Brown, 2015; McDonald \& Ho, 2002; Hu $\&$ Bentler, 1999). Meanwhile, the ratio $\chi^{2} / \mathrm{gl}$ is sensitive to sample sizes exceeding 200 subjects/participants, although scores below 5 are considered acceptable even with the classic criteria (McDonald \& Ho, 2002; Hu \& Bentler, 1999). When assessing effect size in the same models, the classical criteria consider that the minimum threshold for a small size for $\mathrm{r}$ is .10 , for a medium one is .30, and for a large one is .50 (Cohen, 1992). SPSS version 22 and MPLUS version 8.4 were used.

\section{Results}

\section{Primary School Sample}

The values of means, standard deviations, the polychoric correlations of SENA scales, and life satisfaction in the primary sample are shown in Table 2. Asymmetry and

Tabla 2. Descriptive statistics, and polychoric correlations between satisfaction with life, age and SENA's primary scales

\begin{tabular}{lccc}
\hline & Satisfaction with life & $M$ & $S D$ \\
\hline Satisfaction with life & - & 20.91 & 4.57 \\
Age & $-.114^{* *}$ & 10.00 & 0.79 \\
Depression & $-.307^{* *}$ & 1.95 & 0.76 \\
Anxiety & $-.155^{* *}$ & 2.22 & 0.74 \\
Social anxiety & $-.096^{* *}$ & 2.45 & 0.82 \\
Somatic complaints & $-.184^{* *}$ & 2.17 & 0.73 \\
Post-traumatic stress & $-.183^{* *}$ & 2.21 & 0.77 \\
Attention problems & $-.210^{* *}$ & 2.25 & 0.75 \\
Hyperactivity-impulsivity & $-.129^{* *}$ & 1.90 & 0.68 \\
Anger management problems & $-.178^{* *}$ & 1.90 & 0.84 \\
Aggressiveness & $-.121^{* *}$ & 1.30 & 0.48 \\
Defiant behavior & $-.187^{* *}$ & 1.44 & 0.65 \\
Family problems & $-.277^{* *}$ & 1.56 & 0.62 \\
School problems & $-.248^{* *}$ & 1.68 & 0.65 \\
Peer problems & $-.160^{* *}$ & 1.45 & 0.61 \\
Emotional regulation problems & $-.178^{* *}$ & 2.29 & 0.96 \\
Self-esteem & $.329^{* *}$ & 3.95 & 0.79 \\
Social Integration and competence & $.248^{* *}$ & 3.56 & 0.78 \\
\hline
\end{tabular}

$* * p<0.01$ (bilateral). 
kurtosis were outside the acceptable ranges to be considered normally distributed (George \& Mallery, 2010). The analysis of normality at the level of each item found a kurtosis of up to 20 in primary.

It can be seen that life satisfaction correlates significantly and negatively with age and with each of the scales, except with those of personal resources: Self-esteem and Integration, and social competence. The greatest magnitudes in the correlations of satisfaction with life are obtained with self-esteem, depression, and problems with the family. In contrast, the lower ones are obtained with social anxiety and age. It can be noted that only two scales reach a magnitude above 3 .

This already gives a clue about which variables it would be advisable to include in a structural equation model. Nevertheless, before proposing a general model in primary school, each subgroup of variables is analyzed in relation to satisfaction with life, being the subgroups: internalized problems, externalized problems, contextual problems, and personal resources. Among the internalized problems, only depression and anxiety became significant. Among the externalized problems, only Hyperactivity-impulsivity and attention problems were significant. Among the contextual problems, family and school were significant. Both personal resources were significant. All the variables that were significant in the subgroups were entered into an initial model from which model 1 was finally obtained.

\section{Secondary School Sample}

The values of means, standard deviations, and the polychoric correlations of SENA scales and life satisfaction

Tabla 3. Descriptive statistics, and polychoric correlations between satisfaction with life, age and SENA's secondary scales

\begin{tabular}{|c|c|c|c|}
\hline & Satisfaction with life & $M$ & $S D$ \\
\hline Satisfaction with Life & - & 18.67 & 4.66 \\
\hline AGE & $-.108 * *$ & 14.40 & 1.70 \\
\hline Depression & $-.525 * *$ & 2.14 & 0.85 \\
\hline Anxiety & $-.394 * *$ & 2.54 & 0.87 \\
\hline Social Anxiety & $-.271 * *$ & 2.41 & 0.82 \\
\hline Somatic Complaints & $-.365 * *$ & 2.30 & 0.80 \\
\hline Post-Traumatic Stress & $-.358 * *$ & 2.11 & 0.71 \\
\hline Obsessive-compulsive & $-.229 * *$ & 2.14 & 0.74 \\
\hline Attention Problems & $-.279 * *$ & 2.37 & 0.79 \\
\hline Hyperactivity-Impulsivity & $-.181 * *$ & 2.05 & 0.68 \\
\hline Anger Management Problems & $-.262 * *$ & 2.10 & 0.88 \\
\hline Aggressiveness & $-.168 * *$ & 1.39 & 0.50 \\
\hline Defiant Behavior & $-.254 * *$ & 1.60 & 0.72 \\
\hline Anti-Social Behavior & $-.156^{* *}$ & 1.23 & 0.36 \\
\hline substance use & $-.137 * *$ & 1.31 & 0.59 \\
\hline Schizotipia & $-.366^{* *}$ & 1.80 & 0.75 \\
\hline Eating problems & $-.381 * *$ & 2.14 & 0.79 \\
\hline Family Problems & $-445 * *$ & 1.75 & 0.68 \\
\hline School Problems & $-.302 * *$ & 1.85 & 0.69 \\
\hline Peer Problems & $-.188 * *$ & 1.34 & 0.47 \\
\hline Emotional Regulation Problems & $-.369 * *$ & 2.43 & 1.01 \\
\hline Sensation seeking & $-.147 * *$ & 2.30 & 0.89 \\
\hline Self-Esteem & $.519 * *$ & 3.64 & 0.92 \\
\hline Social Integration and Competence & $.319 * *$ & 3.41 & 0.75 \\
\hline Awareness of problems & $-.367 * *$ & 2.48 & 0.83 \\
\hline
\end{tabular}

$* * p<0.01$ (bilateral). 
in the primary sample are shown in Table 3. Asymmetry and kurtosis again were outside the acceptable ranges to be considered as normally distributed (George \& Mallery, 2010). The analysis of normality at the level of each item found kurtosis of up to 30 in secondary. Therefore, the choice of the WLSMV estimator is ratified as the most appropriate.

It can be seen that life satisfaction correlates significantly and negatively with age and with each of the SENA scales, except again with those of personal resources.

It can be seen that in general, the magnitude of the correlations increases, with 9 over .3 , one over .4, and two over .5. The highest correlation of satisfaction with life is with depression, self-esteem, and family, in that order. The least significant correlations are with age and substance use.

Again, although the correlations give a clue about the variables that would be advisable to include in the structural equation model, the same strategy is followed as with primary, analyzing by subgroups, obtaining similar results to those of the primary sample. Among the new scales is the subgroup of other problems.

\section{Structural equation models}

In the primary sample the variables that remained in the final model were depression, school problems, self-esteem, and age. All of them had an effect on life satisfaction. Self-esteem is the only one that reached a medium effect according to the classic criteria mentioned above, while the rest reached a small effect. Additionally, self-esteem is the only one that had a positive effect on life satisfaction. Sex was left out of the model. The indicators of goodness of fit were adequate. Obtained $\chi^{2} / \mathrm{gl}=2.68, \mathrm{RMSEA}=0.036(90 \% \mathrm{CI}=.031 \leq .036 \leq$ $.041), \mathrm{CFI}=0.984, \mathrm{TLI}=0.981, \mathrm{SRMR}=0.085$.

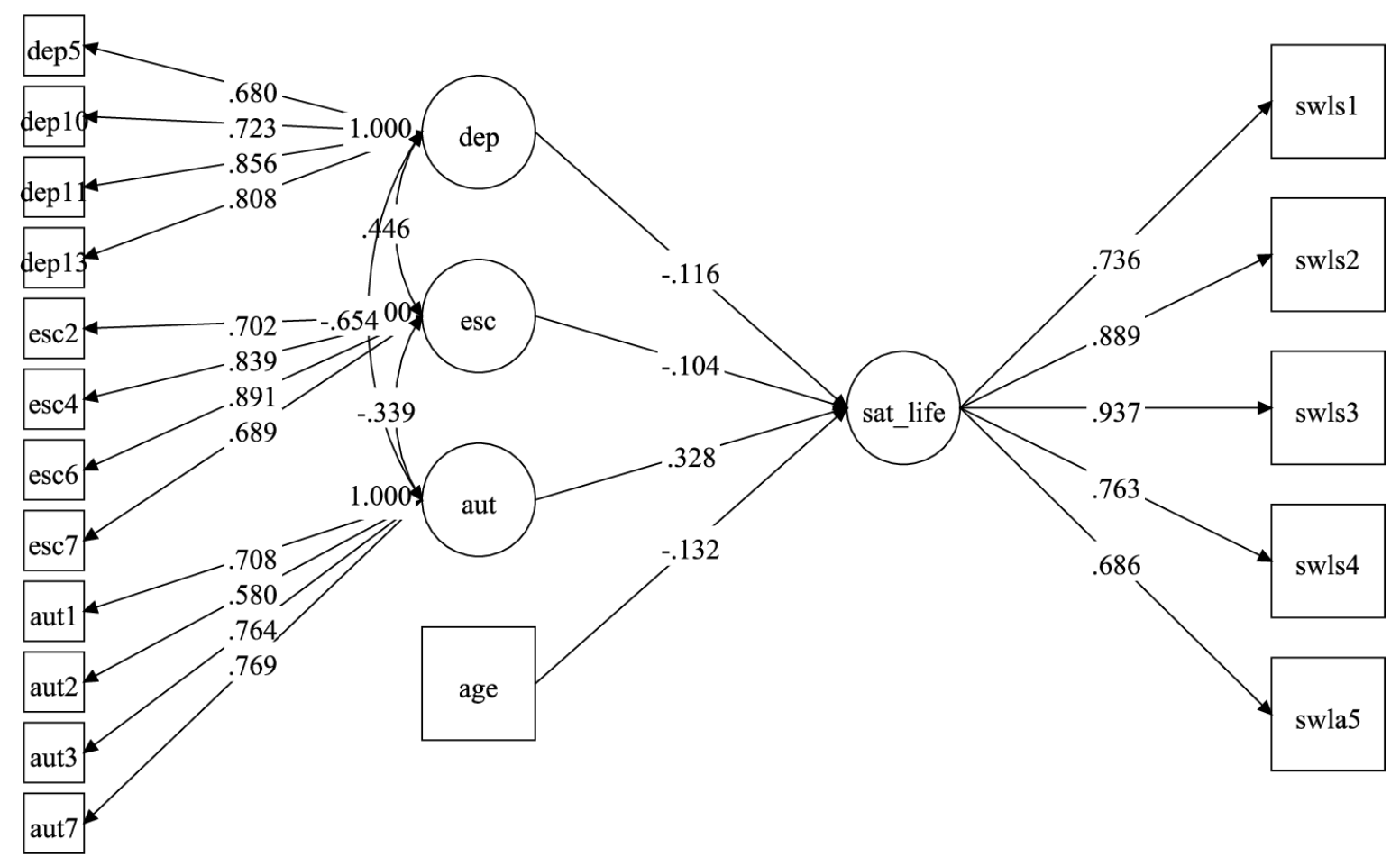

Figure 1. Structural equation model of mental health over life satisfaction in primary sample

Note: Sat_life = satisfaction with life, DEP = depression, ESC = problems with school, AUT $=$ self-esteem. Standardized values are given.

In the high school sample, the variables that remained in the model were depression, problems with family, selfesteem, gender, and age. All of them had an effect on life satisfaction. Self-esteem is the only one that reached an average effect according to the classic criteria mentioned above, while the rest reached a small effect. Again, selfesteem is the only one that had a positive effect on life satisfaction. Unlike the primary, sex remained within the model, with male being associated with greater satisfaction with life.

The indicators of goodness of fit were adequate. It was obtained $\chi^{2} / \mathrm{gl}=6.43, \mathrm{RMSEA}=0.050(90 \%$ $\mathrm{CI}=.048 \leq .050 \leq .053), \mathrm{CFI}=0.977$, TLI $=0.974$, $\mathrm{SRMR}=0.050$. 


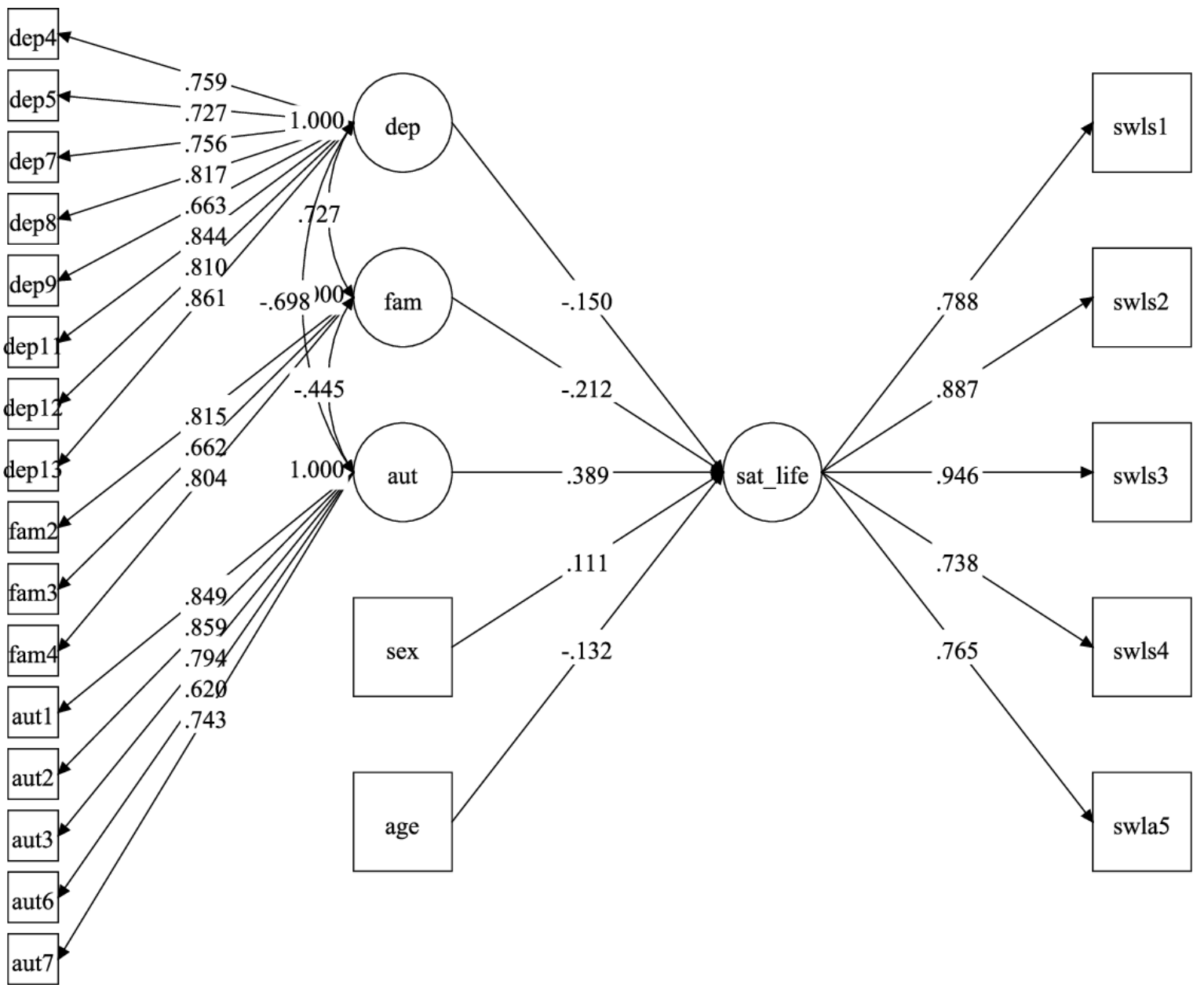

Figure 2. Structural equation model of mental health over life satisfaction in secondary sample

Note: Sat_life $=$ satisfaction with life, DEP $=$ depression, FAM = family problems, AUT = self-esteem. Standardized values are given .

\section{Discussion}

The objective of this study was to analyze the relationship between mental health and life satisfaction in a sample of students from 8 to 18 years old belonging to educational establishments in the city of Arica, located in the North of Chile. Evidence was obtained that partially supports the first hypothesis, referred in part to that internalized problems have a significant negative effect on satisfaction with life. However, specifically, depression was the most prominent variable and the only one of this type that enters both primary and secondary school models. However, this is consistent with the relevance found in a review of depression in this population (Sánchez-Hernández et al., 2014).

No evidence was found to support that externalized problems have a significant negative effect on life satisfaction beyond correlations. At least when considered in conjunction with the rest of the mental health problems in both samples. Therefore, the fact that internalized problems have a more significant effect than externalized ones on life satisfaction, was fully supported. This is consistent with other research (State \& Kern, 2017; Sun \& Shek, 2010, 2012). However, this result has not always been found, although the correlation with the latter remains higher for internalized problems than for externalized ones (McKnight et al., 2002; Suldo \& Huebner, 2004). Although in part this discrepancy may be due to the use of different instruments, it seems quite clear the need to continue investigating this relationship. Beyond finding significant relationships between different types of mental health problems with life satisfaction, this study contributes to a more complex analysis, showing that by introducing all these variables into a structural equation model, the externalized problems were left out. More evidence needs to be accumulated to understand if this is maintained in other studies. 
Partial evidence was obtained to support the second hypothesis, which states that contextual problems have a significant negative effect on life satisfaction. Although it varied in both groups, in primary school problems were the only ones that enter the model. While in secondary school, only family problems were included. It is important to ask why this difference exists, and future research could clarify it. However, the results support Bronfenbrenner's $(1979,1990)$ theory of the importance of context in both samples. It is possible that the normative transition between childhood and adolescence generates more conflict in the family. This stage also coincides with the change between primary and secondary school, which implies a greater challenge to students (Chappel et al., 2014). The research of Gadermann et al. (2016) also obtains evidence in this sense when considering the relationship with adults in the home and in the neighborhood, obtaining a significant correlation with satisfaction with life. This is also consistent with the study carried out by AlfaroInzunza et al. (2019).

Evidence was obtained that partially supports the third hypothesis, referring to personal resources having a significant positive effect on life satisfaction. Specifically, self-esteem is the variable that remains in the models of both samples and is the only one that reaches a medium effect size among all the other variables in both models. This suggests that special attention should be given to interventions that promote life satisfaction. There is at least one study that has had results along the same lines, finding that the personal adjustment component of BASC-2 (Reynolds \& Kamphaus, 2004) is strongly associated with life satisfaction (State \& Kern, 2017). This component includes Interpersonal Relations, Parent Relations, Self-Esteem, and Self-Confidence. It can be observed that in addition to sharing the self-esteem variable with the SENA personal resources index, other scales are similar to the second component of this index, which is integration and social competence. Although this scale is significant if only personal resources are analyzed, it disappears from the models when other relevant variables are included.

Evidence was found that partially supports the fourth hypothesis, that being male is associated with greater life satisfaction. This only happened in the secondary group, since in the primary group, sex did not play a significant role. Using a wider age range than most of the research, it is evident that in children, the gender variable did not play a relevant role in life satisfaction, as it seems to do in adolescents. Being a man becomes an advantage at some point over 12 years, which coincides with previous research on adolescents (State \& Kern, 2017). It is important to question how this difference comes about. One could hypothesize an effect of socialization and culture that teaches a privileged position to male status. It is relevant to consider that in the present study the internalized problems were greater in girls, in line with international literature and epidemiological studies in the same country (Vicente et al., 2012). It is therefore quite logical to assume that since these problems are more closely related to life satisfaction, adolescent girls have lower levels of satisfaction.

The fifth hypothesis, referring to which age has a significant negative effect on life satisfaction, was fully supported in the data, although the effect size is small. This negative relationship between age and life satisfaction contradicts the review by Gilman and Huebner (2003), who do not find an association. But it is in line with others (Goldbecket al., 2007; Haranin et al., 2007), who find a modest negative correlation. However, it is possible to use instruments that consider life satisfaction in a multidimensional way, allowing a complete perspective of its relationship with mental health variables. Meanwhile, it is important to consider in the future whether some type of intervention can mitigate the negative effect of age on life satisfaction.

It is important to pay attention to the source of information being considered to assess life satisfaction and the mental health variables you want to crosscheck. For example, unlike the research of Vicente et al. (2012), in the present study, high school students have greater mental health problems. A crucial aspect of this difference may be that in their research, they use different sources of information, asking parents of young children and interviewing adolescents directly. It is well known that different sources can present quite a bit of discrepancy (Izquierdo-Sotorrio et al., 2021). Now, it would be expected that if we want to know how satisfied children and adolescents are with their lives, we would also ask them directly about their mental health problems.

This research has some limitations. There is no random selection. As it is a cross-sectional study, causality cannot be clearly established, but rather a plausible relationship is hypothesized. Despite the number of variables that were analyzed, it is possible that other variables not considered in the present study could make it much more complex to understand how to predict satisfaction with life. While the sample size is an advantage, it includes only one region of northern Chile.

The fact that a wide range of mental health scales were used is a strength of the present study, which are not usually analyzed together. Another strength of this research has been the use of structural equation 
analysis, which allows a more complex view than other techniques such as multiple linear regression and path analysis because it considers greater error (Lowry \& Gaskin, 2014). Future research could consider random selection, include regions of central and southern Chile, and consider a follow-up over time to see the evolution of variables and their relationships. It would be especially important to evaluate before and after interventions aimed at improving life satisfaction.

The implications of this study aim to focus public policies and interventions on school mental health, emphasizing some key aspects in the promotion of mental health and satisfaction with life. The results obtained suggest that it is necessary to pay special attention to strengthening self-esteem in both groups, as well as to prevention and intervention in depression. Likewise, contextual problems should be included in individual and community interventions, emphasizing the management of problems with school in children and problems with the family in adolescents.

\section{Conflicts of interest}

The authors have no conflicts of interest to declare.

\section{References}

Alfaro-Inzunza, J., Ramírez-Casas Del Valle, L. \& Varela, J. J. (2019). Notions of life satisfaction and dissatisfaction in children and adolescents of low socioeconomic status in Chile. Child Indicators Research, 12, 1897-1913 https://doi. org/10.1007/s12187-018-9618-4

Álvarez, C. A., Briceño, A. M., Álvarez, K., Abufhele, M. y Delgado, I. (2018). Estudio de adaptación y validación transcultural de una escala de satisfacción con la vida para adolescentes. Revista Chilena de Pediatría, 89(1), 51-58. http://dx.doi.org/10.4067/S0370-41062018000100051

American Psychiatric Association (1994). Diagnostic and statistical manual of mental disorders (4 ed.). American Psychiatric Publishing, Inc.

Araya, R., Rojas, G., Fritsch, R., Frank, R. \& Lewis, G. (2006). Inequities in mental health care after health care system reform in Chile. American Journal of Public Health, 96(1), 109-113. https://doi.org/10.2105/AJPH.2004.055715

Bronfenbrenner, U. (1979). The ecology of human development. Harvard University Press

Bronfenbrenner, U. (1990). Discovering what families do. In D. Blankenhorn, S. Bayme y J. B. Elshtain: Rebuilding the nest: A new commitment to the American family (pp. 27-38). Family Service America.

Brown, T.A. (2015). Methodology in the social sciences. Confirmatory factor analysis for applied research. (2nd ed). The Guilford Press.

Calmeiro, L., Camacho, I. \& De Matos, M. (2018). Life Satisfaction in Adolescents: The Role of Individual and Social Health
Assets. The Spanish Journal of Psychology, 21. https://doi. org/10.1017/sjp.2018.24

Campbell, O., Bann, D. \& Patalay, P. (2020). The gender gap in adolescent mental health: a cross-national investigation of 566,827 adolescents across 73 countries. MedRxiv. https://doi. org/10.1101/2020.06.12.20129312

Chappel, A. M., Suldo, S. M. \& Ogg, J. A. (2014). Associations Between Adolescents' Family Stressors and Life Satisfaction. Journal of Child and Family Studies, 23(1), 76-84. https://doi. org/10.1007/s10826-012-9687-9

Cherry, K. M. \& Lumley, M. N. (2019). The Longitudinal Stability and Predictive Capability of Positive and Negative SelfSchemas in a Multi-Informant Study of Child and Adolescent Depressive Symptoms and Life Satisfaction. International Journal of Applied Positive Psychology, 4(1-2), 47-66. https:// doi.org/10.1007/s41042-019-00018-3

Cherry, K. M., McArthur, B. A. \& Lumley, M. N. (2020). A MultiInformant Study of Strengths, Positive Self-Schemas and Subjective Well-Being from Childhood to Adolescence. Journal of Happiness Studies, 21, 2169-2191. https://doi. org/10.1007/s10902-019-00171-1

Coffey, J. K., Warren, M. T. \& Gottfried, A. W. (2015). Does Infant Happiness Forecast Adult Life Satisfaction? Examining Subjective Wellbeing in the First Quarter Century of Life. Journal of Happiness Studies, 16(6), 1401-1421. https://doi. org/10.1007/s10902-014-9556-x

Cohen, J. (1992). Statistical Power Analysis. Current Directions in Psychological Science, 1(3), 98-101. https://doi.org/10.1111/14678721.ep10768783

Diener, E. (2009). Assessing subjective wellbeing: Progress and opportunities. In E. Diener (Ed.), Social indicators research series: Vol. 39. Assessing wellbeing: The collected works of Ed Diener (pp. 25-65). Springer Science + Business Media. https://doi.org/10.1007/978-90-481-2354-4_3

Diener, E., Emmons, R. A., Larsen, R. J., Griffin, S. (1985). The satisfaction with life scale. Journal of Personality Assessment, 49(1), 71-75. https://doi.org/10.1207/s15327752jpa4901_13

Fernández-Pinto, I., Santamaría, P., Sánchez-Sánchez, F., Carrasco, M. A. y del Barrio, V. (2015). SENA. Sistema de Evaluación de Niños y Adolescentes. Manual de aplicación, corrección e interpretación. TEA Ediciones.

Fernández-Pintos, M. E., Daset, L. R. y Castelluccio, L. (2019). Perfil de bienestar psicológico subjetivo en adolescentes uruguayos. Suma Psicológica, 26(2), 103-109. https://dx.doi. org/10.14349/sumapsi.2019.v26.n2.6

Forrest, C. B., Bevans, K. B., Riley, A. W., Crespo, R. \& Louis, T.A. (2013). Health and school outcomes during children's transition into adolescence. Journal of Adolescent Health, 52(2), 186-194. https://doi.org/10.1016/j.jadohealth.2012.06.019

Gadermann, A. M., Guhn, M., Schonert-Reichl, K. A., Hymel, S., Thomson, K. \& Hertzman, C. (2016). A Population-Based Study of Children's Well-Being and Health: The Relative Importance of Social Relationships, Health-Related Activities, and Income. Journal of Happiness Studies, 17(5), 1847-1872. https://doi.org/10.1007/s10902-015-9673-1

Gadermann, A. M., Schonert-Reichl, K. A. \& Zumbo, B. D. (2010). Investigating Validity Evidence of the Satisfaction with Life Scale Adapted for Children. Social Indicators Research. 96, 229-247. https://doi.org/10.1007/s11205-009-9474-1 
George, D. \& Mallery, M. (2010). SPSS for Windows Step by Step: A Simple Guide and Reference (10th ed.). Pearson.

Gilman, R. \& Huebner, S. (2003). A review of life satisfaction research with children and adolescents. School Psychology Quarterly, 18(2), 192-205. https://doi.org/10.1521/scpq.18.2.192.21858

Goldbeck, L., Schmitz, T. G., Besier, T., Herschbach, P. \& Henrich, G. (2007). Life satisfaction decreases during adolescence. Quality of Life Research, 16(6), 969-979. https://doi. org/10.1007/s11136-007-9205-5

Guzmán, J., Green, J. G., Oblath, R. \& Holt, M. K. (2020). Life satisfaction mediates the association between mental health risk and perceptions of school functioning among children and adolescents. Contemporary School Psychology. https:// doi.org/10.1007/s40688-019-00257-w

Haranin, E. C., Huebner, E. S. \& Suldo, S. M. (2007). Predictive and incremental validity of global and domain-based adolescent life satisfaction reports. Journal of Psychoeducational Assessment, 25(2), 127-138. https://doi.org/doi:10.1177/0734282906295620

Hernández, R., Fernández, C. y Baptista, P. (2010) Metodología de la Investigación. McGraw - Hill.

Hu, L. t. \& Bentler, P. M. (1999). Cutoff criteria for fit indexes in covariance structure analysis: Conventional criteria versus new alternatives. Structural Equation Modeling, 6(1), 1-55. https://doi.org/10.1080/10705519909540118

Huebner, E. S. (2004). Research on assessment of life satisfaction of children and adolescents. Social Indicators Research, 66(1-2), 3-33. https://doi.org/10.1023/B:SOCI.0000007497.57754.e3

In, H., Kim, H. \& Carney, J. V. (2019). The relation of social skills and school climate of diversity to children's life satisfaction: The mediating role of school connectedness. Psychology in the Schools, 56(6), 1023-1036. https://doi.org/10.1002/pits.22247

Izquierdo-Sotorrio, E., Carrasco, M. A., Holgado-Tello, F. P. (2020). Rechazo parental y ajuste psicológico infantil: efecto moderador del afecto familiar percibido desde una perspectiva multi-informante. Revista de Psicopatología y Psicología Clínica, 25(3), 195-206. https://doi.org/10.5944/rppc.26961.

Kaye-Tzadok, A., Kim, S. S. \& Main, G. (2017). Children's subjective wellbeing in relation to gender - What can we learn from dissatisfied children? Children and Youth Services Review, 80, 96-104. https://doi.org/10.1016/j.childyouth.2017.06.058

Lawler, M. J., Newland, L. A., Giger, J. T., Roh, S. \& Brockevelt, B. L. (2017). Ecological, Relationship-Based Model of Children's Subjective Wellbeing: Perspectives of 10-Year-Old Children in the United States and 10 Other Countries. Child Indicators Research, 10(1), 1-18. https://doi.org/10.1007/s12187-016-9376-0

Li, C. H. (2016). Confirmatory factor analysis with ordinal data: Comparing robust maximum likelihood and diagonally weighted least squares. Behavior research methods, 48(3), 936-949. https://doi.org/10.3758/s13428-015-0619-7

Lombardo, P., Jones, W., Wang, L., Shen, X. \& Goldner, E. M. (2018). The fundamental association between mental health and life satisfaction: results from successive waves of a Canadian national survey. BMC Public Health, 18(1), 342. https://doi.org/10.1186/s12889-018-5235-x

Lowry, P. B. \& Gaskin, J. (2014). Partial Least Squares (PLS) Structural Equation Modeling (SEM) for Building and Testing Behavioral Causal Theory: When to Choose It and How to Use It. IEEE Transactions on Professional Communication, 57(1-2), 123-146. https://doi.org/10.1109/TPC.2014.2312452
Lyons, M.D., Otis, K.L., Huebner, E.S., \& Hills, K.J. (2014). Life satisfaction and maladaptive behaviors in early adolescents. School Psychology Quarterly, 29(4), 553. https://doi.org/10.1037/ spq0000061

McDonald, R.P., \& Ho, M.-H.R. (2002). Principles and practice in reporting structural equation analyses. Psychological Methods, 7(1), 64-82. https://doi.org/10.1037/1082-989X.7.1.64

McKnight, C.G., Huebner, E.S., \& Suldo, S. (2002). Relationships among stressful life events, temperament, problem behavior, and global life satisfaction in adolescents. Psychology in the Schools, 39(6), 677-687. https://doi.org/10.1002/pits.10062

Moksnes, U.K., \& Espnes, G.A. (2013). Self-esteem and life satisfaction in adolescents-gender and age as potential moderators. Quality Life Research, 22(10), 2921-2928. https:// doi.org/10.1007/s11136-013-0427-4

Moksnes, U., Løhre, A., Lillefjell, M., Byrne, D., \& Haugan, G. (2016). The association between school stress, life satisfaction and depressive symptoms in adolescents: Life satisfaction as a potential mediator. Journal Social Indicators Research, 125(1), 339-357. https://doi.org/10.1007/s11205-014-0842-0

Nesi de Mello, L.T., Trintin-Rodrigues, V., \& Andretta, I. (2019). Relation between social skills and life satisfaction by adolescents and use of applications for communication. Quaderns de psicologia, 21(1), e. 1463. https://doi.org/10.5565/ rev/qpsicologia.1463

Nishida, A., Richards, M., \& Stafford, M. (2016). Prospective associations between adolescent mental health problems and positive mental wellbeing in early old age. Child and Adolescent Psychiatry and Mental Health, 10(12). https://doi. org/10.1186/s13034-016-0099-2

Rescorla, L. A., Achenbach, T. M., Ivanova, M. Y, Harder, V. S., Otten, L., Bilenberg, N., Bjarnadottir, G., Capron, C., De Pauw, S. S., Dias, P., Dobrean, A., Döpfner, M., Duyme, M., Eapen, V., Erol, N., Esmaeili, E. M., Ezpeleta, L., Frigerio, A. \& Verhulst, F. C. (2011). International comparisons of behavioral and emotional problems in preschool children: parents' reports from 24 societies. Journal of Clinical Child \& Adolescent Psychology, 40(3), 456-467. https://doi.org/10.10 80/15374416.2011.563472

Reynolds, C.R., \& Kamphaus, R.W. (2004). Behavior assessment system for children (2nd ed.). American Guidance Service.

Sánchez-Hernández, Ó., Méndez, F. X., \& Garber, J. (2014). Prevención de la depresión en niños y adolescentes: Revisión y reflexión. Revista de Psicopatología y Psicología Clínica, 19(1), 63. https://doi.org/10.5944/rppc.vol.19.num.1.2014.12983

Sánchez-Sánchez, F., Fernández-Pinto, I., Santamaría, P., Carrasco, M. A. \& del Barrio, V. (2016). SENA, Sistema de Evaluación de Niños y Adolescentes: proceso de desarrollo y evidencias de fiabilidad y validez. Revista de Psicología Clínica con Niños y Adolescentes 3(2), 23-34.

Soares, A. S., Pais-Ribeiro, J. L. \& Silva, I. (2019) Developmental assets predictors of life satisfaction in adolescents. Frontiers in Psychology. 10:236. http://dx.doi.org/10.3389/fpsyg.2019.00236

State, T. M. \& Kern, L. (2017). Life satisfaction among high school students with social, emotional, and behavioral problems. Journal of Positive Behavior Interventions, 19(4), 205-215. http://dx.doi.org/10.1177/1098300717714573

Suldo, S. M. \& Huebner, E. S. (2004). Does life satisfaction moderate the effects of stressful life events on psychopathological 
behavior during adolescence? School Psychology Quarterly, 19(2), 93-105. http://dx.doi.org/10.1521/scpq.19.2.93.33313

Sun, R. C. F. \& Shek, D. T. L. (2010). Life satisfaction, positive youth development, and problem behaviour among chinese adolescents in Hong Kong. Social Indicators Research, 95(3), 455-474. http://dx.doi.org/10.1007/s11205-009-9531-9

Sun, R. C. F. \& Shek, D. T. L. (2012). Positive youth development, life satisfaction and problem behaviour among chinese adolescents in Hong Kong: A replication. Social Indicators Research, 105(3), 541-559. http://dx.doi.org/10.1007/ s11205-011-9786-9

Valois, R., Zullig, K. J., Huebner, E. S. \& Drane, J. W. (2004). Life satisfaction and suicide among high school adolescents. Social Indicators Research Series, 81-105. http://dx.doi. org/10.1007/978-1-4020-2312-5_5

Valois, R., Zullig, K. J., Huebner, E. S., Kammermann, S. K. \& Drane, J. W. (2002). Association between life satisfaction and sexual risk-taking behaviors among adolescents. Journal of
Child and Family Studies, 11(4), 427-440. http://dx.doi. org/10.1023/A:1020931324426

Vicente, B., Saldivia, S., De la Barra, F., Melipillán, R., Valdivia, M. \& Kohn, R. (2012). Salud mental infanto-juvenil en Chile y brechas de atención sanitarias. Revista médica de Chile, 140(4), 447-457.http://dx.doi.org/10.4067/s0034-98872012000400005

World Health Organization (2017). Depression and other common mental disorders: global health estimates. https://apps.who. int/iris/handle/10665/254610

Zhu, X. \& Shek, D. T. L. (2020). The Influence of Adolescent Problem Behaviors on Life Satisfaction: Parent-Child Subsystem Qualities as Mediators. Child Indicators Research, 13, 1767-1789. https://doi.org/10.1007/s12187-020-09719-7

Zullig, K. J., Valois, R. F., Huebner, E. S., Oeltmann, J. E. \& Drane, J. W. (2001). Relationship between perceived life satisfaction and adolescents' substance abuse. Journal of Adolescent Health, 29(4), 279-288. http://dx.doi.org/10.1016/ S1054-139X(01)00269-5 